Interdisciplinary Contexts of Special Pedagogy
NUMBER 26/2019

\title{
Doing and undoing gender by women with intellectual disabilities
}

\begin{abstract}
Edyta Zierkiewicz, Beata Cytowska, Doing and undoing gender by women with intellectual disabilities. Interdisciplinary Contexts of Special Pedagogy, no. 26, Poznań 2019. Pp. 271-293. Adam Mickiewicz University Press. ISSN 2300-391X. e-ISSN 2658-283X. DOI: https://doi.org/10.14746/ikps.2019.26.13
\end{abstract}

The aim of this article is to present socio-cultural processes of doing gender categories in women with intellectual disabilities and to identify barriers and limitations which they face on the way of "becoming women".

The study and its analysis are based on the critical approach.

The method of data collection was a participant observation conducted during three proprietary workshops on femininity organized for 17 women with moderate to severe intellectual disabilities (5-6 people in a group), attending an occupational therapy workshop. The aim of our workshops was the empowerment of one's own femininity and strengthening of processes of doing gender by the participants.

The analysis of collected material revealed that the process of shaping gender identities of women with intellectual disability is a subject of social control of the local community. Participants of the workshops are well aware that they are adult women and they strive for the realization of cultural patterns of femininity. In their case, however, these patterns are socially regulated and the women themselves internalize certain limitations imposed by the society during the socialization process. They instinctively "know" what they are allowed to do, and what they cannot gain as women with intellectual disabilities.

KEY WORDS: woman, intellectual disability, (un)doing gender, femininity, workshops, critical approach 


\section{Introduction}

The subject of the analysis presented herein comprises processes of doing gender by women with intellectual disability, or rather barriers and limitations encountered by them in "becoming women". This issue remains, in principle, outside the area of interests of disability researchers. In scientific publications, usually only "a student", "a graduate", "an adult", "an employee" etc. or "a person" with intellectual disability is discussed as if they functioned in a utopian post-gender world, where gender no longer has any meaning. Perhaps, the researchers rather assume that other topics are more important and urgent to discuss than common, obvious issues of gender. We adopt a different position, in compliance with which, we understand gender as a social institution ${ }^{1}$ and a structure of social relations. " "Personal identities, patterns of gendered embodiment, intimate contacts - all of these »close-up « experiential issues, which are usually the topic of discussion on gender - are constituted in the structure of gendered relations. This structure always comprises men and women and assumes different forms of masculinity and femininity" ${ }^{3}$ Those patterns are adopted, reproduced and negotiated/transformed in social relations, where individuals and groups function. ${ }^{4}$ Furthermore, the quoted author explains that "gender refers to the manner in which the society copes with the human body and the reproduction process, as well as numerous consequences of this »coping « in our personal and social life". 5

${ }^{1}$ J. Lorber, Believing is Seeing: Biology as Ideology, "Gender and Society", 1993, no. 7(4), pp. 568-581.

2 R. Connell, Advancing Gender Reform in Large-scale Organizations: A New Approach for Practitioners and Researchers, "Policy and Society" 2005, no. 24(4), pp. 5-24.

${ }^{3}$ R. Connell, Advancing Gender Reform in Large-scale Organizations: A New Approach for Practitioners and Researchers, "Policy and Society" 2005, no. 24(4), p. 6.

${ }^{4}$ R. Connell, Gender: In World Perspective (Socjologia ptci. Płeć w ujęciu globalnym), transl. O. Siara, PWN, Warsaw 2013, p. 30.

${ }^{5}$ R. Connell, Gender: In World Perspective (Socjologia ptci. Płeć w ujęciu globalnym), transl. O. Siara, PWN, Warsaw 2013, p. 31. 
In the further part of the text we would like to present, how gender "works" as a social structure in the case of women with intellectual disability, that is, how it shapes (including: how it blocks) their functioning, as well as how it is perceived and doing by them. We believe, similarly to, Connell, that gender is multidimensional, liquid and can be produced by us in various ways, e.g. depending on the social context. We will present our considerations on the grounds of the data collected during three educational workshops with participation of women with intellectual disability. However, first of all, we will briefly explain the concept, which is key for our considerations.

\section{Gender as regulatory fiction - the theoretical basis of the analysis}

The concept of doing gender 6 is usually explained as recreating by women the dominant model of femininity (and model of masculinity by men), in compliance with social expectations, however, as if it was a natural phenomenon not requiring thought or specific skills (here: gender competences ${ }^{7}$ ). The reality is different; becoming and then, "being" a woman (or a man) is a process in which the individual becomes engaged as soon as they are born and which continues throughout their life.

Many people believe that roles of women and men are not socially played, but rather biologically conditioned and therefore, universal, obvious and ahistorical. Biology, which only as of the end of the 19th century "has explained" gender differences ${ }^{8}$, as a science

${ }^{6}$ Cf. C. West, D.H. Zimmerman, Doing Gender, "Gender and Society" 1987, no. 1(2), pp. 125-151.

${ }_{7}$ R. Connell, Gender: In World Perspective (Socjologia ptci. Płeć w ujęciu globalnym), transl. O. Siara, PWN, Warsaw 2013, p. 170.

8 Previously, this issue was discussed mainly by theologists, according to whom "God created a man and a woman for different purposes". Therefore, first, social inequalities constituted the adopted effect of the "Divine Law", and when "biological differences between women and men were recognised as a scientific fact (...), 
is perceived, not only by laypersons, as functioning above suspicion of any bias; it is believed to be an axiom that it simply describes natural facts. Nevertheless, as noticed by, among others, Judith Lorber, "Western ideology treats biology as the cause and the social behaviour and positions as the effect, then, it constructs biological dichotomies to justify »naturalness « of gendered behaviours and gendered social statuses. Thus, we believe what we see: two sexes produce two genders. However, this process happens inversely: the gender constructs social bodies so that they are different and unequal" $^{\prime \prime}$. Critical reflections presented by Lorber or e.g. Richard Lewontin (1996) lead to the observation that such binary understanding of the issue of sex (female/male) and gender (women/men) is an arbitrary procedure that remains in contrast to both, biological10, as well as socio-cultural reality.

Despite popularised scientific discoveries and anthropological analyses, people still, in majority thoughtlessly, refer to the strongly rooted in the western culture belief that gender is a derivative of sex that "its meanings inscribed in anatomically diversified bodies are characterised with a certain determinism, whereas, the bodies only passively wait for the implacable law to work" ${ }^{11}$ The quoted author

[then,] all attempts at objection against (...) discrimination of women [proved to be] a violation of the "laws of nature «" (M. Kimmel, The Gendered Society (Spoteczeństwo genderowe), transl. A. Kłonkowska, GWP, Gdansk 2015, pp. 42-43).

${ }^{9} \mathrm{~J}$. Lorber, Believing is Seeing: Biology as Ideology, "Gender and Society", 1993, no. 7(4), p. 568. The fact that the language of biology is biased was proved by many authors, among others, Emily Martin, who, on the grounds of the analysis of ways of describing oocyte and sperm in academic textbooks, demonstrated that the language of the scientific - seemingly neutral - description is soaked with gender stereotypes (cf. E. Martin, The Egg and the Sperm: How Science Has Constructed a Romance Based on Stereotypical Male-Female Roles. (Jajo i plemnik. Naukowy romans), transl. J. Włodarczyk, [in:] „Gender. Perspektywa antropologiczna”, ed. R. Hryciuk, A. Kościańska, Warsaw 2007.).

${ }^{10}$ E.g. M. Kimmel, The Gendered Society (Społeczeństwo genderowe), transl. A. Kłonkowska, GWP, Gdansk 2015, pp. 41-88.

${ }^{11} \mathrm{~J}$. Butler, Gender Trouble: Feminism and The Subversion of Identity (Uwiktani w płeć. Feminizm i polityka tożsamości), transl. K. Krasuska, „Krytyka Polityczna”, Warsaw 2008, p. 54. 
underlines that this customary manner of understanding gender constitutes a function of the discourse, which "is based on binary structures, which appear as the language of universal rationality". The fact that, until recently we could not imagine that there are more than two sexes or two genders (or that we still feel resistance thereto) results from the limitations, which are "already built-in in the notion of cultural sphere of gender allowed by language".12 The seemingly obvious observation that sex is binary (which is supposed to be proved by primary sex features) leads to the conclusion that "»men« are (...) an addition to biologically male bodies or that »Women « constitute an interpretation of solely female bodies". ${ }^{13}$ Therefore, for many it can be even more difficult to accept the following analytical conclusion: that "sex is always defined as gender". ${ }^{14}$ However, the author accurately explains which measures and tools are used so that the "apparatus of production and establishing sex"15 works effectively and thus, invisibly. She indicates, among others, the binarism underlining the discursive ordering of the world, including the establishment of apparent opposites: strong will - determinism, mind/soul - body, culture - nature, gender - sex, etc. The relation in this dichotomous system to some extent assumes that one element constitutes a reverse of the other, therefore, if one results from intentional intervention, the other exists independently of social action, is more primary. Stability of the biological construction of sex is guaranteed by inscribing it in

$12 \mathrm{~J}$. Butler, Gender Trouble: Feminism and The Subversion of Identity (Uwiktani w płeć. Feminizm i polityka tożsamości), transl. K. Krasuska, „Krytyka Polityczna”, Warsaw 2008, p. 56.

$13 \mathrm{~J}$. Butler, Gender Trouble: Feminism and The Subversion of Identity (Uwiktani w pteć. Feminizm i polityka tożsamości), transl. K. Krasuska, „Krytyka Polityczna”, Warsaw 2008, p. 51.

$14 \mathrm{~J}$. Butler, Gender Trouble: Feminism and The Subversion of Identity (Uwiktani w płeć. Feminizm i polityka tożsamości), transl. K. Krasuska, „Krytyka Polityczna”, Warsaw 2008, p. 55.

$15 \mathrm{~J}$. Butler, Gender Trouble: Feminism and The Subversion of Identity (Uwikłani w płeć. Feminizm i polityka tożsamości), transl. K. Krasuska, „Krytyka Polityczna”, Warsaw 2008, p. 52. 
the pre-discourse sphere and, therefore, in consequence, people come to believe that it is natural, inalienable and gender constitutes a specific opposite thereto. 16 The power apparatus blurring traces of discursive creation of such feeling constitutes the "comprehensibility matrix", which defines sex as "substance, being identical as self", whereas, it hides the fact that "»being " sex or gender if fundamentally impossible". ${ }^{17}$ Nevertheless, the majority of us thoughtlessly state that we are "a woman/feminine" (or "a man/masculine"), not noticing in this gesture the limiting activity of hegemonic discourse using the binary regulation of sexuality. ${ }^{18}$ Effectiveness of the discourse is reinforced with the presence of other fundamental belief in our culture: concerning the substantial, psychological person ("real, inner Me"). This person is "disclosed" in the statement "I am a woman" ("I am a man") expressing the wish to be a causative subject (i.e. "being a cause for own thoughts") and simultaneously transforming "fictitious wholes, which at the beginning had only linguistic reality" in substance. ${ }^{19}$ And thus, there is a significant shift in discourse, which leads to the conclusion that "a person is a gender in culture and that it is so due to own sex, mental feeling of self and various manners of expressing own psychological »me«, out of which the most noticeable is sexual desire". ${ }^{20}$

16 J. Butler, Gender Trouble: Feminism and The Subversion of Identity (Uwiktani w płeć. Feminizm i polityka tożsamości), transl. K. Krasuska, „Krytyka Polityczna”, Warsaw 2008, p. 53.

$17 \mathrm{~J}$. Butler, Gender Trouble: Feminism and The Subversion of Identity (Uwiktani w płeć. Feminizm i polityka tożsamości), transl. K. Krasuska, „Krytyka Polityczna”, Warsaw 2008, pp. 70-71.

18 J. Butler, Gender Trouble: Feminism and The Subversion of Identity (Uwiktani w płeć. Feminizm i polityka tożsamości), transl. K. Krasuska, „Krytyka Polityczna”, Warsaw 2008, p. 71.

19 J. Butler, Gender Trouble: Feminism and The Subversion of Identity (Uwikłani w płeć. Feminizm i polityka tożsamości), transl. K. Krasuska, „Krytyka Polityczna”, Warsaw 2008, pp. 74-75.

${ }^{20} \mathrm{~J}$. Butler, Gender Trouble: Feminism and The Subversion of Identity (Uwiktani w płeć. Feminizm i polityka tożsamości), transl. K. Krasuska, „Krytyka Polityczna”, Warsaw 2008, p. 76. 
A cultural requirement that all of us are subjected to (and which we are negotiating or trying to oppose) constitutes having a stable, unequivocal and, preferably, "correspondent" to our sex, identity (including: gender identity). In psychology - e.g. in Erik Erikson's conception ${ }^{21}$ - it is assumed that an individual in their development process should undertake the task of self-formation (i.e. of own identity) at the relatively early stage, i.e. in the adolescence period, at approx. 16 years old. Currently, this task, as many other previously limiting adulthood, is postponed in time (memorandum), yet, still the majority of people lack the awareness that the "postulate of identity is a cultural limitation - a principle introducing order and hierarchy, in short: regulatory fiction".22 "Women" and "men" continue to be understood as permanent substances, yet, this "substantial effect of gender is performatively created and becomes obligatory by regulatory practices of its coherence. (...) [G]ender is always an activity, however, not the activity of an individual that would proceed their action". ${ }^{23}$ In short, the author of the Gender Trouble (Uwikłani w płeć) states: "Gender constitutes a repeated body stylisation, a collection of acts repeated in exceptionally rigid regulatory framework, which solidify with time, creating an appearance of substance, an appearance of a certain type of natural being". ${ }^{24}$

Biological features of women and men considered as key and varied in quality, for many centuries enabled unequivocal classification of people to one of two separate social categories. In contemporary Western societies this mechanism "gets stuck", since ideologi-

${ }^{21}$ E. Erikson, Identity and the Life Cycle (Tożsamość a cykl życia), transl. M. Żywicki, Zysk i S-ka, Poznan 2004, pp. 84-90.

${ }^{22} \mathrm{~J}$. Butler, Gender Trouble: Feminism and The Subversion of Identity (Uwiktani w płeć. Feminizm i polityka tożsamości), transl. K. Krasuska, „Krytyka Polityczna”, Warsaw 2008, p. 79.

${ }^{23} \mathrm{~J}$. Butler, Gender Trouble: Feminism and The Subversion of Identity (Uwiktani w płeć. Feminizm i polityka tożsamości), transl. K. Krasuska, „Krytyka Polityczna”, Warsaw 2008, p. 80.

${ }^{24} \mathrm{~J}$. Butler, Gender Trouble: Feminism and The Subversion of Identity (Uwiktani w płeć. Feminizm i polityka tożsamości), transl. K. Krasuska, „Krytyka Polityczna”, Warsaw 2008, p. 94. 
cal beliefs legitimising its functioning are disclosed, discussed and questioned, as well as various subversive practices with regard to the heteronormative order are undertaken. More and more people come across journalistic debates and scientific considerations regarding, whether gender is achieved, done and (in various ways) implemented and not "authoritatively" assigned. It seems that nowadays, gender is more and more often perceived as "a task to perform", or rather a manner to express inner Me, or desirable stylisation of own body.

The explanations referred above should help us present the phenomenon of performative gender creation, i.e. the activity of regulatory fiction constituting gender with regard to persons, who are often excluded from population of "real women" or function at its margin.

\section{Methodology}

The main objective of our research, as has already been mentioned, constituted the analysis of the phenomenon of doing gender (creating gender identity), in which women with intellectual disability are engaged. The research was situated in a critical paradigm. In compliance with the critical approach, the researcher's task is to uncover linguistic violence and hidden power relations. Women with intellectual disability encounter numerous limitations in the process of creating gender identity or even rejection in this regard from their environment. In this text we want to answer the question, how, in the case of women with intellectual disability, the process of socialising to gender roles attributed to females occurs or does not occur. Therefore, we will strive to identify moments when the mechanism of regulatory fiction usually acting through "the unambiguity of sex, internal cultural coherence of gender and binary frameworks of sex and gender" 25 is "stuck".

${ }^{25} \mathrm{~J}$. Butler, Gender Trouble: Feminism and The Subversion of Identity (Uwiktani w płeć. Feminizm i polityka tożsamości), transl. K. Krasuska, „Krytyka Polityczna”, Warsaw 2008, p. 94. 
The presented research has been conducted during educational workshops aimed at supporting the process of empowering participants - women with more severe intellectual disability. While establishing the organisation of workshops, we conducted several focus interviews to distinguish areas important for adult women with intellectual disability ${ }^{26}$. One of the conclusions from conducted focuses, which we would like to refer here, harmonised with findings of our researchers and it concerned numerous barriers blocking emancipatory efforts undertaken by persons with intellectual disability. ${ }^{27}$ Moreover, a category of gender as "an element" repeated many times during interviews was also strongly distinguished in our results. As a result of conducted analyses, gender proved to be a meta-issue entering into "interactions" with each distinguished topic. Therefore, the interviews implied that the research participants, despite considering themselves as females, are not deemed as real women in the social context and experience many limitations in performing life roles typical for women. Due to recognising one of the most arduous and unclear for the focus interviewees' difficulties, we decided to devote the educational workshops to the issue of femininity and thus, the identity, which they "aspire" to achieve.

To conduct the workshop (in three different groups) we had invited a professional with many years of experience in working with persons with intellectual disability, a psychologist, supported employment coach, who proprietarily selected methods and detailed contents to the topic stipulated beforehand. Our participation in the workshop consisted in observing (participant observation) and registering its course, however, we sometimes helped participants if

${ }^{26}$ B. Cytowska, E. Zierkiewicz, Conversations about health - sharing the personal experiences of women with intellectual disabilities, "Journal of Applied Research in Intellectual Disabilities"), 2020.

27 Cf. B. Cytowska, Difficult Ways of Adaptation. Emancipation Themes in the Analysis of the Situation of Adults with Intellectual Disabilities in the Contemporary Polish Society. (Trudne drogi adaptacji. Wątki emancypacyjne w analizie sytuacji dorostych osób $z$ niepetnosprawnościa intelektualną we współczesnym społeczeństwie polskim), Oficyna Wydawnicza „Impuls”, Kraków 2012. 
directly requested e.g. in drawing a picture they came up with or writing down a specific phrase on paper.

The workshop was participated by a total of 17 women with more severe intellectual disability aged $24-48$ years old (3 groups of 5-6 persons), living in various environments and attending two Lower Silesian Occupational Therapy Workshops.

Each workshop lasted approx. 3-4 hours with half-an-hour break. Participation was voluntary and all participants had been asked individually, if they agreed to being recorded during workshops. Furthermore, all women had been ensured that the information would be used anonymously and the information identifying them would be omitted. Moreover, we agreed that at any moment of the project they could resign from participation in classes.

After completion, each workshop was described in details and statements given by the trainer and participants were transcribed.

\section{Workshops for women with intellectual disability as social space for community definition of female identity}

In compliance with our assumptions, the process of constructing gender identity has a relational character and is executed with specific social activities and practices, in which the entity, in the given context, engages (and is engaged). Our position is contrary to the still popular belief that femininity is a highly abstract concept category, which can be understood solely by achieving a specific level of cognitive development (i.e. formal thinking exceeding the concrete and experience, characterised with the ability to generalise, deduct and conclude). ${ }^{28}$ Moreover, understanding own femininity would supposedly naturally stem from the "inside" of the individual, who, by achieving a specific level of maturity, can disclose and express this truth about oneself. In reality, since birth we participate

${ }^{28}$ Cf. J. Piaget, Inhelder B., The Psychology of the Child (Psychologia dziecka), transl. Z. Zakrzewska, Siedmioróg, Wroclaw 1996, p. 120. 
in processes of doing gender and we acquire certain gender competences quite early, which allow us to find ourselves in the world popularised by, so to say, two separate groups: women and men.

Such dichotomous thinking of gender is still widespread in common believes and intensively supported by media images, and even scientific works, e.g. psychological. ${ }^{29}$ Of course, there are many more social powers pressuring the individual to "properly" create their gender identity. Additionally, persons with intellectual disability are pressured to "create disability", that is, impose on them specific beliefs regarding their ability and various, presumably protective, limitations. Analysis of the material collected during workshops allowed noticing three of such pressures, which were disclosed in the approach, believes and behaviours of the psychologist conducting the workshop, as the person organising and ordering the social space of the meeting and representing the institutional power. By indicating the phenomenon of "forming" objects of activity in compliance with the previously adopted vision, we do not want to criticise the person conducting the workshop, who completed the training task very well, but to draw attention to the fact that taking a certain role (here: the teacher, the trainer of the group, the organiser of the workshop etc.) entails unconsciously exercising certain pressures related to the functioning of given regimes, among others, institutional and gender. Noticing this entanglement is extremely difficult.

Therefore, first of all, our analysis disclosed the meaning of the trainer's believes on cognitive and emotional functioning of participants of classes as persons with intellectual disability. These believes were not communicated directly but were manifested with a surprise at a lack of expected reactivity of participants of the first workshop and by changes introduced in exercises with two following groups. Secondly, the source of pressure also consisted in the professional experience of the trainer establishing her believes. Years of professional work enable workers to establish and main-

${ }^{29}$ Cf. R. Connell, Gender: In World Perspective (Socjologia ptci. Płeć w ujęciu globalnym), transl. O. Siara, PWN, Warsaw 2013, p. 110 and next. 
tain contact with supported persons, but, at the same time, result in the former internalising norms and rules of the institution, which they later enforce from the latter. The third type of pressure disclosed in the analysis should be connected with the topic of workshops, i.e. defining femininity and undertaking actions with regard to biographical gender designs. ${ }^{30}$

The psychologist conducting the workshop quite quickly gained "an idea" regarding cognitive abilities and limitations of participants of the first workshop (she familiarised herself with this group effectively, since she knew some of those persons earlier and she met them in her work). As, at the beginning her questions regarding who a woman is and what femininity is were not elaborated on by the participants, the trainer did not go into reasons for silence and she reached for props: dialogue cards presenting females often in unreal or symbolic manner (e.g. as a matryoshka, with a house on the head, with butterflies on the head, with a teddy bear in the belly). The exercise to which women had been invited, consisted in selecting one image from a pack of 30 cards and describing it to a colleague sitting next to them. Work in pairs was also welcomed quite reluctantly, therefore, the trainer changed the form of the exercise to work in a group. She asked participants to present their card to the others and explain their choice; to facilitate the task, the participants were asked to answer the question, what they liked about the picture (or what they did not like). Yet another time the trainer faced resistance from the group; this time, a little smaller. As it seems, participants started to get accustomed to the situation and undertook the task describing elements observed in the image to others. They mainly used simple, very precise terms, such as: "I have a lady dancing on water and she dances like this, moves her leg and hand like this. Here, she has a dress, here she has a scarf tied, here she has shoes and I like that she is dancing nicely". Other constructed this statement: "I see a woman leaning, she is watching something", without giving reasons for selecting the card. "I can

${ }^{30}$ R. Connell, Gender: In World Perspective (Socjologia ptci. Płeć w ujęciu globalnym), transl. O. Siara, PWN, Warsaw 2013, p. 172. 
try... But I do not know, what to say. She has something on her head, I do not know, a castle. (...) Because I liked this card. Because she has something on her head, she holds something".

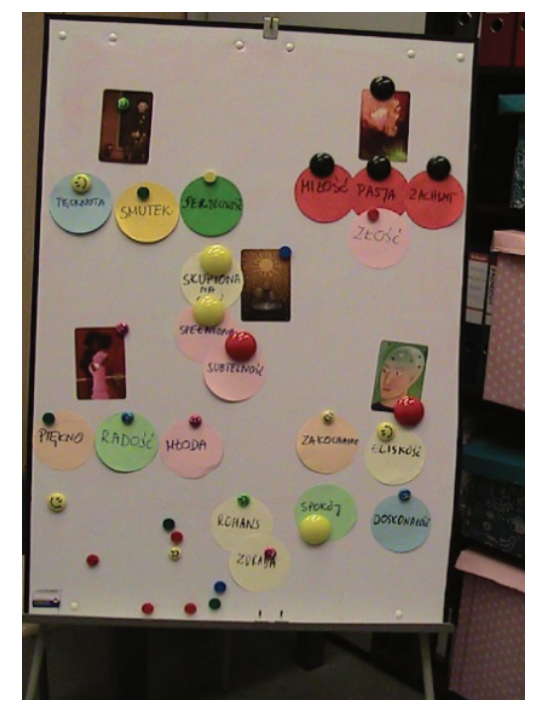

Photo no. 1

The trainer did not comment behaviours and statements made by participants, she did not lecture them; she tried to adjust to them (or rather to her interpretation of their intellectual and social abilities at a given moment). However, it seems she assumed that the proposed exercises are too difficult for women and they showed a low level of language constructions and complete misunderstanding of symbolism in the pictures, since in two consecutive workshop groups the trainer changed the use of cards significantly. In the modified task, the participants could, instead of forming own opinions, use definitions signed on prepared cards (photo no. 1). The majority of studied individuals participating in all three workshops could read and those who did not manage with reading were 
helped by the trainer, who gave them several propositions to choose from. Some of those were metaphorical or abstract, yet, women matched them to the selected card correctly.

The first exercise in unmodified version (group 1) and in modified version (groups 2 and 3) - allowed participants to get used to the unusual situation, relax and engage in further parts of the workshop. Women showed openness, they expressed their opinions more willingly and, if they did not hear or understand the request, they were not afraid to ask for repetition or explanation. They also started helping each other or asked the psychologist for support. In that way e.g. new terms were learned or less frequently used terms were repeated, such as: subtlety, fulfilment, passion, concentration, longing and similar concepts were differentiated: love and infatuation, admiration and joy.

After this part of workshops, the trainer asked all participants what they understand by femininity. The manner of giving answers varied: persons from group 1 who did not have hints in a form of cards with ready statements, used descriptive phrases, where practices and gendered activities were underlined: "A woman is pregnant", "She has to feed, she has boobs", "Put make-up on, get dressed", "Taking care of personal hygiene", "Dying hair", "Painting nails", "Puts lipstick on", "A woman wears earrings", "She is in love", "Yes, she loves her man". Apart from the above, the participants recalled associations with appearance, indicating the process of "creating" feminine image with the use of various cosmetics (related to makeup). It could be stated that their statements to some extent indicated the beautification regime domineering in culture, as the "natural capital" of women (gender capital, aesthetic capital $^{31}$ ), and simultaneously "deciphering" that femininity is a kind of disguise ${ }^{32}$, or, as we have already written, it is "doing" in repeated behaviours, stylised gestures etc.

31 See. K. Huppatz, Reworking Bourdieu's 'Capital': Feminine and Female Capitals in the Field of Paid Caring Work, "Sociology" 2009, no. 43(1).

32 Womanliness as Masquerade by J. Riviere, cf. as cited in: G. Gajewska, Masquerade of Gender, that is, Non-woman Pretending to be a Woman (Maskarada ptci, czyli nie- 
In contact with two other groups, where the trainer decided to interfere in the group work to "improve" it, a significant phenomenon of relative construction of femininity and "helpful" use of regulatory fiction is observed. Participants from groups 2 and 3 in their statements on the meaning of the concept of femininity did not use phrases referring to social performance, but to psychological, internal "nature" of women. These definitions (and depictions) became available to them by: a) previously prepared cards with terms referring to personality-related feminine features, $b$ ) vocabulary suggested to them during the exercise by the trainer, and c) by own agreements made during the group discussion. Therefore, mainly two dimensions of gender regime appeared in the conversations held by participants of groups 2 and 3, called by Connell the dimension of emotions and human relations ${ }^{33}$ (e.g. indicating that women are characterised with sensitivity, protectiveness) and the dimension of gender ideology (here: mainly the roles "assigned" to women: a mother and a wife).

\section{Biological, but not cultural determinism? Social limitations of the possibility to "implement" gender identity by women with intellectual disability}

As we have already mentioned, the majority of people do not reflect deeply on the essence of gender identity and mechanisms of creating it. It is still commonly believed that gender roles and gender result directly from primary sex features: female or male genitalia (unambiguous cases, e.g. androgyny, are "invalidated" surgically). Sex is considered to be primary and unequivocal. However, this common sense approach to women and men is difficult in use, since

kobieta udająca kobietę), "Miscellanea Anthropologica et Sociologica" 2017, no. 18(2), p. 59.

${ }^{33}$ R. Connell, Advancing Gender Reform in Large-scale Organizations: A New Approach for Practitioners and Researchers, "Policy and Society" 2005. 
we meet nude persons in social situations extremely rarely - and only in this way we can state their sex. Therefore, every day we "identify" others only on the grounds of their appearance and behaviour, which can result in misunderstandings in contacts with them. ${ }^{34}$ Avoiding social faux pas, difficulties or more serious problems (resulting from e.g. social ostracism due to the non-adherence to gender norms), people usually send quite clear signals regarding sex, which has been assigned to them and/or with which they identify. In the direct and indirect, via media, living environment of contemporary people, since early childhood they are presented with ideal and, much less frequently, alternative models of gender behaviours, which they should copy. Expectations regarding fulfilment of relevant roles (or rather roles corresponding with their sex) are being constantly formulated etc.

The process of doing gender happens to some extent unnoticed or not fully consciously and, in majority of cases it happens efficiently and effectively. Trajectories of gender development cease to proceed collision-free, among others, when gender designs are not or cannot be coherent with the model of femininity (or masculinity) available in the culture. ${ }^{35}$ Admittedly, in the contemporary world we do observe relaxation of gender regimes and individualisation of the approach to construct gender identities, however, this case extremely rarely concerns persons with intellectual disability. What is interesting, those are the persons who are at the disposal of a considerable "subversive potential" exceeding narrow and rigid models of femininity (or masculinity). However, the use of this "arsenal" by persons with intellectual disability is objected by basically all of their social environment: parents, carers, teachers, pedagogues, psychologists, friends, neighbours and others. Therefore, they are subjected to intensified and very special social control

${ }^{34}$ M. Kimmel, The Gendered Society (Społeczeństwo genderowe), transl. A. Kłonkowska, GWP, Gdansk 2015, pp. 168-169.

35 R. Connell, Gender: In World Perspective (Socjologia ptci. Płeć w ujęciu globalnym), transl. O. Siara, PWN, Warsaw 2013, p. 172. 
aimed at (and resulting from) doing gender in compliance with their sex and simultaneously limiting or hindering it, that is, undoing gender.

Women with intellectual disability are identified by, among others, medical personnel or own parents, as women, because they have female genitalia. Thus, they are socialised and brought up in compliance with the binding model of femininity, however, they are more often and more intensively than their typical peers subjected to control interventions, presented to them as undertaken for their own good, for their safety, hygiene and care. Whereas, such treatments above all violate their privacy and intimacy, infringe their individual rights (including to experience their sexuality), biological functions of their bodies are subjected to stigmatism and embarrassment. In consequence, thus repressed individuals, despite their bodies biologically maturing, almost never, in social sense, become adult women (i.e. their environment still often does not give them such status); they do not "receive" the right to enter into relations with intimate partners (the more so, to get married and start families), the right to make life choices independently and often, even to purchase basic clothes (they receive T-shirts, bras or even underpants from their mothers). And despite the fact that majority of them are not legally incapacitated, to some extent they are socially and politically made a non-person (dependent, non-adult, irresponsible) - culturally disabled. Paradoxically, or rather contrary to the assurances made by the environment (among others, parents) such hindrance or blocking (in social and political context) gender identity implementation and limiting it to physiological and sexual functions of body (especially, to the "nuisance" with menstruation, "danger" of getting pregnant, "horror" of starting sexual life) is executed due to the interest of all of the other persons apart from the woman with intellectual disability.

We refer to the important and uncomfortable for many social entities, issue, since it shows how complex the matter of creating gender by persons with intellectual disability is. The physiological aspect of their functioning is so deeply "naturalised" that they be- 
come to some extent "biology of their organism", that is, females, who - for many never - should not become cultural individuals: women. What for typical persons is only a starting point, for them is to be the ending point. Of course, it is not possible to implement such dystopian postulate, therefore, women with intellectual disability have a considerate subversive potential, as they create other, different, exceptional, marginal, alternative etc. gender identities significantly different from the dominant model and thus, they show that this model is only a certain cultural construction and not a biological and cultural destiny of each female.

The objective of our workshops was to start a conversation with women with intellectual disability on the topic of their possibilities in doing gender and mutually explore factors blocking such processes. Therefore, the next task proposed by the trainer consisted in, generally speaking, the participants situating themselves as a woman in social reality and more accurately: in social roles.

The psychologist asked women from group 1 to draw themselves and then to draw persons with whom they have close relations and at the end to write their characteristic features in the drawing (persons who had difficulties with writing dictated the text to the trainer). This task was not successfully completed by the group; one woman refused drawing, the other wanted to destroy the picture, because she was not happy with it ("I look like a tramp"), and the other stated that it did not look like she wanted, although, after a moment she found similarity to her mother in the self-portrait. While observing drawing women, one paradoxical phenomenon was noticed: on the one hand, they were in general happy with the drawing; however, on the other hand, in various ways, they expressed disappointment with the results or rather, they communicated dislike to themselves and low self-esteem. This situation is only seemingly contradictory and atypical. In fact, a majority of women do not accept their appearance; cultural ideals of feminine beauty are very difficult to achieve and in comparison to such models one should refer while assessing own image. Participants of this training expressed these cultural mandates they regu- 
larly come across in the mass media and not only. To some extent, they even played with this dissatisfaction, as if they performed for themselves and their friends.

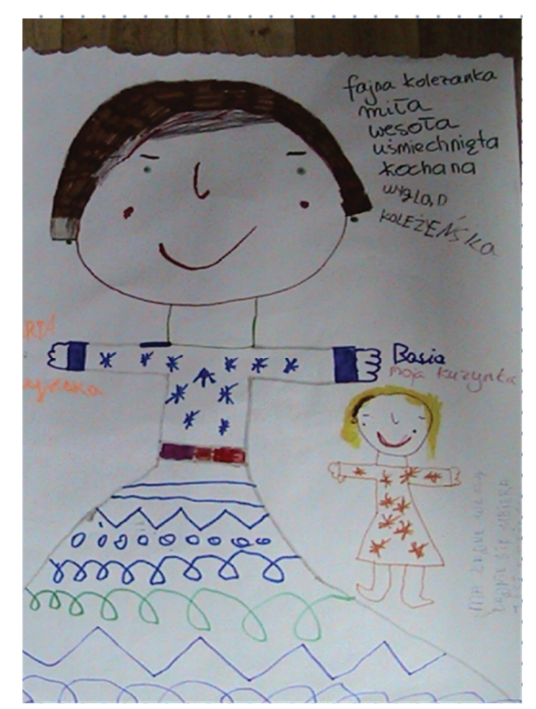

Photo no. 2

Despite undertaking the activity of drawing, the subjects from group 1 did not want to talk about themselves or to write down their characteristic features, therefore, the person conducting the workshop had to change this formula and proposed that the participants wrote down attributes admired and appreciated in their colleagues in the group (photo no. 2). This task was performed by the participants more willingly. They described their colleagues only with positive features: "she is polite, cheerful", "she is smiling, laughing", "kind", "nice", "she is pretty", "lovely", "she is a good colleague", "a woman", "friendly". When features enumerated by their colleagues were read out, the described participants were visibly happy - they had been openly appreciated. 


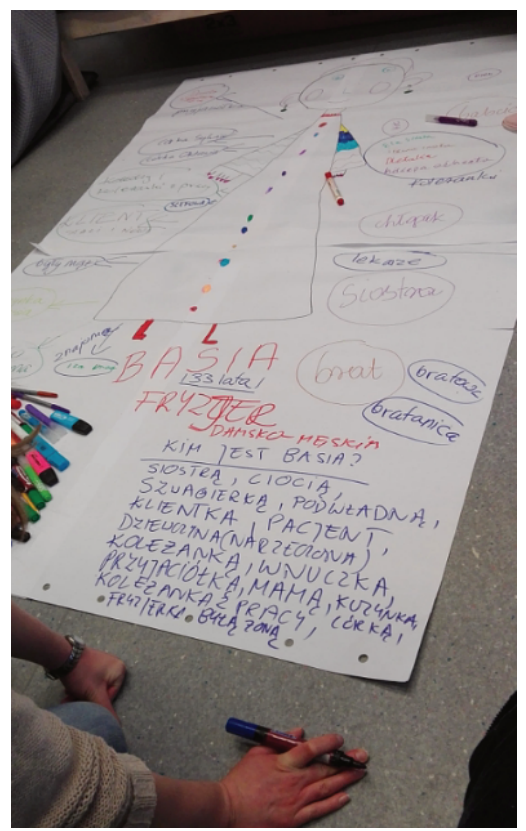

Photo no. 3

In remaining groups (2 and 3 ) the trainer changed this task as well to a mutual drawing of a picture of one woman (!) and creating her biography: who she is, how old she is, what her profession and hobby is, whom she has close relations with (photo no. 3). This modified idea was again, as believed by the trainer, successful (she did not introduce any modifications in group 3). Participants of group 2 and 3 performed the task with more enthusiasm than their colleagues. They were daydreaming about the imagined woman and, what is interesting, they used several terms that they had learned (or remembered) during previous exercise regarding defining femininity.

To sum up, it is worth underlining that participants from group 1 , directed by the trainer, described each other as persons making a friendly impression, easy in contact. At that, they referred or even 
turned directly to the particular person. They did not refer to the category of femininity as key to characterise themselves or their social relations. The situation was completely different in groups 2 and 3, where a story was made up about an imagined, single female as if symbolising the whole population of women. This type of exercise reinforces the gender regime and refers to certain perceptions concerning social expectations formulated with regard to women. However, participants of both groups evidently used their own resources, therefore, doctors appear among important persons with whom they have relations. "Facilitating" or perhaps "enabling" work with workshops' participants, the trainer clearly directed them to cultural socialisation strategies and reinforced gender regimes.

\section{Summary}

When a child is born, in common perception, in fact, a girl (future woman) or a boy (future man) is born. From the very beginning, parents and other persons from the child's environment undertake actions that will create proper, in terms of gender, environment, among others, they buy specific toys (dolls or cars), they dress her/him in clothes adjusted to sex (skirts or trousers), pay attention that thy use proper grammatical forms, as well as daydream with the child about his/her adult life: occupation, family (of course, heterosexual) and children that will be born from this relationship: a girl or a boy. The whole process is smooth and almost unnoticed, however, only if "everything is fine" the child, or rather it is able to adjust to the existing normative order. However, if the child is "different" e.g. homosexual, transgender or has intellectual disability, this process "gets stuck" and is distorted and particular stages of socialisation are not automatic, they are even blocked by carers as undesirable.

Special "others" do not have social consent to, among others, get married and have children (and if the latter happens, then, as in the case of women with intellectual disability, children are taken from them and given up for adoption). They are not allowed to routinely 
undergo the "natural" social process; nevertheless, they do undergo this process, yet, differently. Thus, their presence in the society discloses existence of the cultural socialisation mechanism, which results in effectively engaging social entities in "gender doing" processes and therefore, in responding to the call to embody and internalise gender norms. Nevertheless, it seems that in majority, carers of persons with intellectual disability concentrate so much on controlling their behaviours or desires that they do not notice the potential of persons under their care, which is revolutionary with regard to the social order. Besides, it is not something desirable for them and for the whole environment. However, they cannot allow to completely ban their disabled children from forming gender identity, since our whole life is lived within the gender system, which operates through images, language, relations, behaviour, appearance etc.

At the same time, in the case of women with intellectual disability, being recognised as women is often an aspirational objective they link with adulthood, freedom of choice, independence and full rights. However, due to considering them as persons with intellectual disability they are refused to "be" ("real") women. Therefore, usually, they acquire only a certain scope of gender competences, so as to make it possible to recognise, where the social barrier between "being" a woman and "being" a disabled (woman) was set. Paradoxically, our workshops allowed disclosing both of these processes: doing gender in compliance with the dominant models of femininity, which was actively participated by the psychologist conducting the training and undoing gender, which constituted participants' response to reaching the invisible barrier separating them from implementing the call imposed on (almost) all women.

\section{Bibliography}

[1] Butler J., Uwikłani w płeć. Feminizm i polityka tożsamości, transl. K. Krasuska, Krytyka Polityczna, Warsaw 2008.

[2] Connell R., Advancing Gender Reform in Large-scale Organizations: A New Approach for Practitioners and Researchers, "Policy and Society" 2005, no. 24(4), pp. 5-24. 
[3] Connell R., Socjologia ptci. Płeć w ujęciu globalnym, transl. O. Siara, PWN, Warsaw 2013.

[4] Cytowska B., Zierkiewicz E., Conversations about health - sharing the personal experiences of women with intellectual disabilities, "Journal of Applied Research in Intellectual Disabilities", 2020, DOI: 10.1111/jar.12718.

[5] Cytowska B., Trudne drogi adaptacji. Wątki emancypacyjne w analizie sytuacji dorostych osób z niepetnosprawnościa intelektualna we wspótczesnym społeczeństwie polskim, Oficyna Wydawnicza „Impuls”, Kraków 2012.

[6] Erikson E., Tożsamość a cykl życia, transl. M. Żywicki, Zysk i S-ka, Poznan 2004.

[7] Gajewska G., Maskarada ptci, czyli nie-kobieta udająca kobiete, "Miscellanea Anthropologica et Sociologica" 2017, no. 18(2), pp. 53-64.

[8] Huppatz K., Reworking Bourdieu's 'Capital': Feminine and Female Capitals in the Field of Paid Caring Work, "Sociology" 2009, no. 43(1), pp. 45-66.

[9] Kimmel M., Społeczeństwo genderowe, transl. Anna Kłonkowska, Gdańskie Wydawnictwo Pedagogiczne, Gdansk 2015.

[10] Lorber J., Believing is Seeing: Biology as Ideology, "Gender and Society" 1993, no. 7(4), pp. 568-581.

[11] Martin E., Jajo i plemnik. Naukowy romans, transl. J. Włodarczyk, [in:] Gender. Perspektywa antropologiczna, ed. R. Hryciuk, A. Kościańska, V. 2, Warsaw 2007, pp. 33-49.

[12] Piaget J., Inhelder B., Psychologia dziecka, transl. Z. Zakrzewska, Siedmioróg, Wroclaw 1996.

[13] West C., Zimmerman D.H., Doing Gender, "Gender and Society" 1987, no. 1(2), pp. 125-151. 